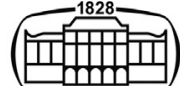

AKADÉMIAI KIADÓ

UNIVERSITY of DEBRECEN

\section{International Review of Applied Sciences and Engineering}

$12(2021) 3,257-268$

DOI:

$10.1556 / 1848.2021 .00267$

(c) 2021 The Author(s)

\title{
Developing railway supplier selection excellence using business intelligence knowledge management framework
}

\author{
Mailasan Jayakrishnan ${ }^{1 *} \odot$, Abdul Karim Mohamad ${ }^{1}$ and \\ Mokhtar Mohd Yusof ${ }^{2}$
}

\author{
${ }^{1}$ Centre for Advanced Computing Technology, Faculty of Information \& Communication \\ Technology, Universiti Teknikal Malaysia Melaka, Hang Tuah Jaya, 76100, Durian Tunggal, Melaka, \\ Malaysia \\ ${ }^{2}$ Faculty of Computer and Information Technology, Al-Madinah International University, Pusat \\ Perdagangan Salak 2, No.18, Jalan 2/125e, Taman Desa Petaling, 57100, Kuala Lumpur, Malaysia
}

Received: February 26, 2021 • Accepted: April 8, 2021

Published online: May 20, 2021

ORIGINAL RESEARCH PAPER

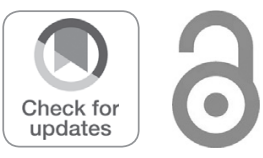

*Corresponding author. E-mail: m031620010@student.utem. edu.my

\begin{abstract}
In a broad scope, the term Information System (IS) is a scientific field of research study that approaches the scope of managerial, strategic, and operational activities complex in the storing, processing, distributing, gathering, and utilizing of knowledge and its associated technologies in organizations and industry. The model of railway supplier selection using BI-KM framework is situated on a horizontal structure of the organization and its technology transformation to execute the organization goal, with technology as enabler and driver (technology adoption), organization as the principal environment (business process analysis), and Information Management (data modeling). This study is significant in supporting data scenarios by focusing on the heuristic view of an industry approach to problem-solving management issues. Furthermore, the research development was to identify integrated framework adoption that contributes to strategic performance diagnostics dashboard. By understanding the factors of theoretical framework adoption, these conceptual frameworks assure competitive advantage. Besides, this railway supplier selection excellence model analyzed the extent and provides a potential solution to strategic decision-making issues. The study directs to regulate the adoption of the theoretical framework towards conceptual framework by using the role of Business Intelligence (BI) to analyze the quality of data presented as the railway supplier selection criteria from operational management through data analytics. Moreover, this will be united to help the best cycles and instruments in essential execution by the executives of a railway supplier selection dashboard for simulating data as interactive supplier performance.
\end{abstract}

\section{KEYWORDS}

business intelligence, decision support system, information system, knowledge management, railway supplier selection

\section{INTRODUCTION}

Business Intelligence (BI) Knowledge Management (KM) is raising to elucidate information surplus and knowledge dispense to enhance decision-making in the industry. Being able to have practical research knowledge by developing the BI-KM excellence framework for an industry is a lifetime experience. Thus, dynamics inside the industry are quickly changing. There is a huge divergence in managerial and workforce direction in the industry. With the expansion in the technology revolution, the necessity of the transformation is changing drastically. The industry is currently hunting for expertise in creativity and innovation comparatively more than impartial covet capability. These changing directions designate a symbiosis model of organizational excellence which expound on the complexity of the 
industry, due to the agitated and prompt change of an organization's domain, Information System (IS) have reshaped the principles of an organization in numerous techniques.

The models of organizational excellence have changed with technology development in the world. The incessantly changing technology revolution, currently, stipulates an advanced model of organizational excellence. According to [1], the ultimate decade possesses comprehension of the unexpected appearance of the new, technology revolution. The industry currently is scrutinizing for expertise that will extract their organization further. The technology disciplines are changing quickly [2]. With such a changing schedule, it is a pre-requisite for organizations to have a group of experts with creative and innovative ideas. The industry is presently assisting advanced technology rather than perceiving them as a threat and unwanted for the organization's performance. Thus, the changing dynamics have unfastened barriers for an advanced model of organizational excellence: the symbiosis, assembling the information disciplines beyond the traditional academic spectrum of discipline for better understanding the information discipline, fact and apposite to a very extensive range of perspectives of information solutions assembled beyond the spectrum of traditional disciplines in an organization. IS transpired as a discipline in the 1960s, by striving to define itself, its relationship, and its scope with its adjacent disciplines in the management and computing domain [3]. In Table 1, we are situating the information disciplines above the traditional academic domain, as a model of Information Technology (IT) disciplines and areas of professional bodies.

Based on Table 1, the scope of IS and its relationship between the technical and business disciplines, fringe a domain of instrumentalist and applied topics, where System Analysis mapped with Individual and Organizational Behaviour, Decision Support Systems (DSS) mapped with
Information Management (IM) and Project Management mapped into IT Management. This technology revolution encounters the vital driver of change in an industry. Whether technology is alternative rather than precisely a driver and perhaps the core of the IS disciplines, implementing general system theories to the rise of computing consign the respective computing levels, where such computing system can be intentional as a human system, software system, social system, or mechanical system by the sociologists, engineers, computer scientists, and psychologists. The utilization of computers to industrial, administrative, government, and commercial advantages require the development of software, where computing as at the mechanical level, include a human level as much as an information level (software) and eventually a community level, to structuring, designing, and analyzing information as data for an organization to engage with their direction of its activities.

Since then, it has become isolated from the mainstream of IS and IT. IT defines the application of hardware and software, with a user implied. It further acknowledges the necessity for enhancement and maintenance and not precisely of software, yet equally with business processes that integrated the intellectual, manual, and automated features. Meanwhile, human level has been categorized as the $\mathrm{Hu}-$ man-Computer Interaction (HCI), a person in front of the computer, human with IT system, and psychological, physical, and informational levels by exchanging meanings, while IT systems exchange information. The IS discipline possesses powerful attention on technology-in-use and application software and hardly on system software and hardware [4]. Various IS scholars have debated the foundations and nature of IS which have their origin in other reference disciplines such as Mathematics, Engineering, Computer Science, Cybernetics, Management Science, and others [5].

Table 1. Model of Information Technology (IT) Disciplines and Areas of Professional Bodies

\begin{tabular}{|c|c|c|c|c|c|}
\hline \multirow{2}{*}{$\frac{\text { Professional Bodies }}{\text { Engineering }}$} & \multicolumn{5}{|c|}{ Information Technology (IT) Disciplines } \\
\hline & Engineering Graphics & Machine Tools & $\begin{array}{l}\text { Engineering } \\
\text { Design }\end{array}$ & Materials Science & $\begin{array}{l}\text { Production } \\
\text { Management }\end{array}$ \\
\hline $\begin{array}{l}\text { Computer Systems } \\
\text { Engineering (CSE) }\end{array}$ & $\begin{array}{c}\text { Electronic Materials \& } \\
\text { Devices }\end{array}$ & Digital Circuitry & Signal Analysis & Control \& Comm & ation Theory \\
\hline \multirow[t]{4}{*}{ Computer Science (CS) } & Software Engineering & $\begin{array}{l}\text { Operating } \\
\text { systems }\end{array}$ & Robotics & Concurrency & $\begin{array}{l}\text { Numerical } \\
\text { Computing }\end{array}$ \\
\hline & Artificial Intelligence & $\begin{array}{l}\text { Formal } \\
\text { Language } \\
\text { Theory }\end{array}$ & $\begin{array}{l}\text { Computational } \\
\text { Theory }\end{array}$ & $\begin{array}{l}\text { Computational } \\
\text { Construction }\end{array}$ & Logic \\
\hline & Computer Architecture & Algorithms & Data Structures & $\begin{array}{c}\text { Networks \& } \\
\text { Communications } \\
\text { Graphics }\end{array}$ & Discrete Math's \\
\hline & Programming & Data Analysis & $\begin{array}{c}\text { Database } \\
\text { Management }\end{array}$ & Knowledge-B & Systems \\
\hline Information Systems (IS) & $\begin{array}{c}\text { Systems Analysis }+ \\
\text { Individual and } \\
\text { Organizational Behaviour }\end{array}$ & \multicolumn{2}{|c|}{$\begin{array}{l}\text { Decision Support Systems (DSS) + } \\
\text { Information Management (IM) }\end{array}$} & Project Management & T Management \\
\hline $\begin{array}{l}\text { Commerce and Business } \\
\text { Administrator }\end{array}$ & $\begin{array}{l}\text { Financial and Cost \& } \\
\text { Management Accounting }\end{array}$ & Microeconomics & Audit & Marketing & Business Law \\
\hline
\end{tabular}


At present, technology encounters drifted to the fringe of IS and Information Management (IM) has become extra important, with its significance on information architecture, meta-data, information retrieval, and semantics. If IT design is about computing that enhances programming and equipment prerequisites, then the socio-specialized plan is about computing that augments network and individual necessities also. In socio-specialized design, modern "users" of computing are referring to the network [6]. The original concept of socio-technical design extension of data extracted and utilized in synchronicity with a model of current and future organizational excellence by extracting from outside the organization-models transpire solicited to "what is" analysis.

\subsection{Research problem}

Most agencies are driven by their own (silo) specific vision and mission and are not yet subscribed to any national policy. Sharing transparent information is generally not yet an organizational culture. At most of these organizations, communications are relative to organizational hierarchy, and power and information exchange among and between the various agencies and sectors is at present quite limited. There is a frantic search for better and modern approaches, tools, and techniques in IS Development and addressing the unavoidable creative agitation between the nature of people and computers between structured systems and the process of evolving. The domain of study in IS has presumed the study of practices and theories parallel to the technological and social phenomena, which prompt the effects, development, and use of IS in society and organization [7]. The information has use and meaning through specific knowledge transformation, especially in problematic scenarios and responses [8]. It advances the user with the knowledge to make imperative decisions. Yet, numerous organizations experience a variance of information, conception changes, and data analytics inaccuracy required to the maturation of comprehensive point of view in appealing attributes of socio-specialized aspects of human conduct highlights.

This dilemma is additionally due to humans lacking information to describe key level data "vulnerable side", particularly on an ordinary example of successful tricky situations and reactions. The target of the research is to discover the appropriation characteristic of an integrated framework towards developing the conceptual framework for strategic performance. A decision-making system is an analytics-data framework, integrated for:

1. providing key information on the data and changing information investigation in an organization to help dynamic capacities and activity management.

2. proposing future technology developments undergo contains BI and Knowledge Management (KM).

3. designing a real-time railway supplier selection dashboard.

Besides each have materialized a fad driven by management specialist "new bottles for old wine", yet each retains the drive to focus on specific features of the complete insights drawn into the IS discipline from other disciplines and to scrutinize domains. The necessity for a formalized stipulation in organization excellence is stronger nowadays than ever before because organizations depend on their technology to perform just-in-time planning for everything that organizations do. Therefore, what we require is to develop new things, initiate around innovations, and contribute to the progress of the organization excellence.

\section{LITERATURE REVIEW}

We intend to discover what railway supplier selection excellence currently necessitates in the designation of IS knowledge, competencies, and skills, as well as any other, to indicate requirements such as technology skills and organization characteristics. The Organizational Learning (OL) perspective of IS research is a critical dimension of an organization, which has arisen positioned to analyze the scenarios over organizations relation yet its relationship, to understand the behavior through some theoretical framework and approach or world views used in organizational analysis. It represents the organization situation within natural OL as well as its concern with the intellectual decision-making procedure of different characteristics about IS abilities on knowledge of the organization world [9]. For that basis, we are deploying the modern theories of organizational communication classification as:

\subsection{Rethinking the organization}

The surmise among the four (4) approaches to theorizing about the organization are the postpositive approach, interpretive approach, critical approach, and postmodern approach. For theorists, their surmise implicit three (3) decisions as ontology (how things are existing), epistemology (how things are known), and axiology (what is worth knowing), as shown in Table 2.

\subsection{Rethinking communication}

Scholars have categorized communications into three (3) models of theories that formulate communication as: information processing (1) linear model, (2) interactional model, and (3) transactional model.

2.2.1. Linear model. In this framework, thriving receiving and sending of a message is an activity of the organizational volume to handle indicator abasement caused by static noise (physical-environment noises that create the message harder to hear, semantic-complexity in perception option of words, psychological prejudices and predispositions that determine how the message is interpreted and physiological impairments such as stiffness of hearing) on the string, as signified in Fig. 1.

Based on Fig. 1, the linear model of communication travels in a straight line that consists of sender (the inventor of communication or the knowledge origin determine inclination communication), encoder (the transmitter which 
Table 2. The approaches to theorizing about the organization

\begin{tabular}{|c|c|c|c|c|}
\hline \multirow[b]{2}{*}{ Theorizing } & \multicolumn{4}{|c|}{ Approaches to Organizations } \\
\hline & Postpositive Approach & Interpretive Approach & Critical Approach & Postmodern Approach \\
\hline Ontology & Realism. & Relativism. & Realism. & Relativism. \\
\hline $\begin{array}{l}\text { How things are } \\
\text { existing? }\end{array}$ & $\begin{array}{l}\text { Organizations possess an } \\
\text { objective reality that is } \\
\text { independent of the } \\
\text { workforce in them. }\end{array}$ & $\begin{array}{l}\text { Organizations approach } \\
\text { actuality and are then } \\
\text { preserve through their } \\
\text { workforce } \\
\text { communication. }\end{array}$ & $\begin{array}{l}\text { The ability information } \\
\text { of an organization } \\
\text { possesses an objective } \\
\text { actuality formed by } \\
\text { cultural influence and } \\
\text { external history. }\end{array}$ & $\begin{array}{l}\text { Organizations advance } \\
\text { into actuality as } \\
\text { temporary integration of } \\
\text { interest against the } \\
\text { cautionary fluidity of } \\
\text { massive historical and } \\
\text { cultural discourses. }\end{array}$ \\
\hline Epistemology & Observation. & Interpretation. & Critique. & Deconstruction. \\
\hline $\begin{array}{l}\text { How are things } \\
\text { known? }\end{array}$ & $\begin{array}{l}\text { Since the workforce } \\
\text { eventually selects actions } \\
\text { that acquire the best } \\
\text { organizational results. }\end{array}$ & $\begin{array}{l}\text { To assimilates an } \\
\text { organization through } \\
\text { clear observation of } \\
\text { organization behaviors. }\end{array}$ & $\begin{array}{l}\text { Revealing the ability } \\
\text { composition in } \\
\text { organizations that is } \\
\text { practiced through } \\
\text { comprehensive theories } \\
\text { and framework to } \\
\text { analyze the specific } \\
\text { organization. }\end{array}$ & $\begin{array}{l}\text { Organizations can be } \\
\text { read through their } \\
\text { historical and cultural } \\
\text { dimension that guide the } \\
\text { criteria of a specific } \\
\text { organization's ability. }\end{array}$ \\
\hline Axiology & Intervention. & Description. & Emancipation. & Denaturalization. \\
\hline $\begin{array}{l}\text { What is worth } \\
\text { knowing? }\end{array}$ & $\begin{array}{l}\text { Scientific research } \\
\text { triggers the knowledge } \\
\text { that can be utilized to } \\
\text { forge predictive theories } \\
\text { and solicit organizational } \\
\text { management practices. }\end{array}$ & $\begin{array}{l}\text { Research focuses on the } \\
\text { workforce designation, } \\
\text { which can be utilized to } \\
\text { develop comprehensive } \\
\text { theories and solicited the } \\
\text { organization's practices. }\end{array}$ & $\begin{array}{l}\text { Research focuses on } \\
\text { power formation in the } \\
\text { organizations that } \\
\text { counter and becomes } \\
\text { achievable. }\end{array}$ & $\begin{array}{l}\text { The current challenge } \\
\text { between organizational } \\
\text { communication, and } \\
\text { organizational knowledge } \\
\text { focus on model relations. }\end{array}$ \\
\hline $\begin{array}{l}\text { Purpose of Organization } \\
\text { Communication }\end{array}$ & $\begin{array}{l}\text { Instrumental. } \\
\text { The impact of the } \\
\text { workforce on the } \\
\text { functional and actions for } \\
\text { communication. }\end{array}$ & $\begin{array}{l}\text { Negotiation. } \\
\text { Organizations utilized } \\
\text { communication to forge } \\
\text { a perception of the } \\
\text { organization's } \\
\text { environment. }\end{array}$ & $\begin{array}{l}\text { Distortion. } \\
\text { Communication in the } \\
\text { organizations works } \\
\text { systemically. }\end{array}$ & $\begin{array}{l}\text { Contestation. } \\
\text { Organizational process } \\
\text { the conversation through } \\
\text { varied channels. }\end{array}$ \\
\hline
\end{tabular}

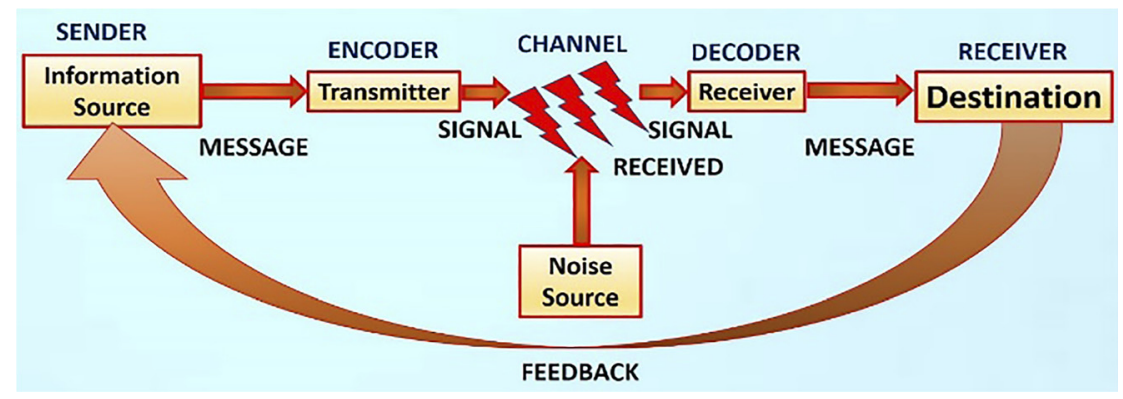

Fig. 1. Linear model of communication travels in a straight line

transforms the communication into indication), receiver (the objective of the communication from sender) and noise (the message is transported from encoder to decoder via the medium. During this procedure, the communication may be affected or be distracted by visible noise like crowd and thunder noise, or encoded signals may deflect in the medium through the communication activity).

2.2.2. Interactional model. This model illustrates communication as a two-way interaction, which incorporates context, determined by the communication environment, that may influence significant and discipline of the trial-the structure of cultures and the reference that individual members present to the transmission, as presented in Fig. 2.

Based on Fig. 2, the interactional model of communication travels in a circular process in which members are both receivers and senders of messages. Communication is received and sent, decoded, interpreted, and encoded by receiver and sender, its countless procedures interactive. Still, the model illustrates communication as one member distributes up a message (inaugurates a message) and the 


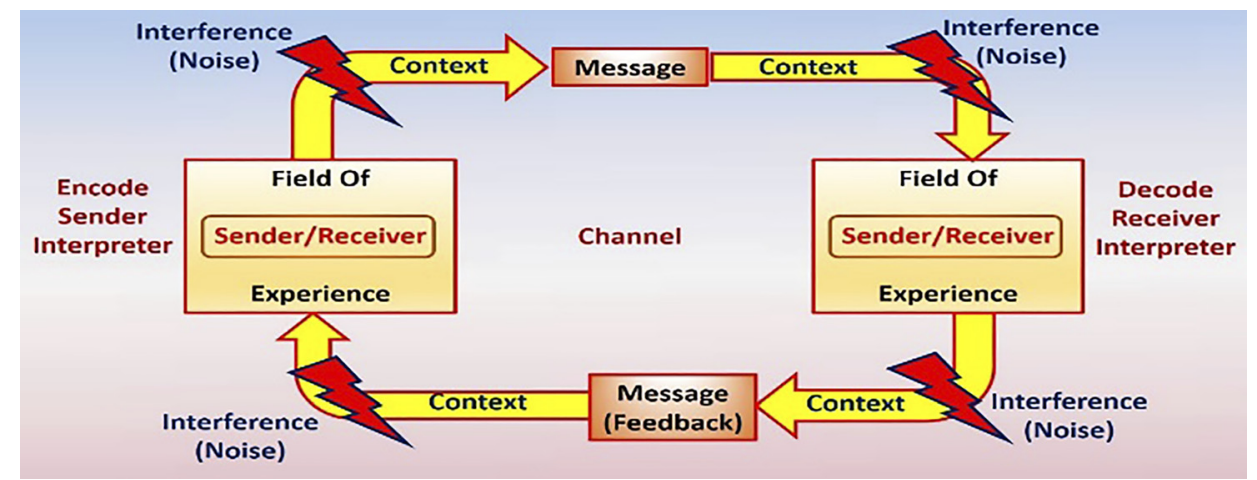

Fig. 2. Interactional model of communication travels in a circular process

other member then makes a return (awaits till the other replies).

2.2.3. Transactional model. The framework illustrates transmission as a synchronous chronicle, where feedback and messages are changed at the identical time linking communicators. They are attached simultaneously in the compact, their discipline of incident overlaps, where practical conceptualization such as context and noise can further be included in the model, as signified in Fig. 3.

Based on Fig. 3, the transactional model of communication travels in a simultaneous process, to exceed understanding within the organization communication, where we will go beyond the functional models, message-centered, and meaning-centered approach. Yet, further theorists surmise the significance of a message is something that the receiver and sender contrive together as they interact with their communication. Furthermore, we characterize the seven (7) defined traditions of communication theory as a discipline shown in Table 3.

Based on Table 3, the seven traditions of communication theory, we present seven (7) approaches of communication scenario of information that needs to keep on going with an intended meaning.
Table 3. The seven traditions of communication theory

\begin{tabular}{|c|c|}
\hline Theoretical Tradition & Communication Theory \\
\hline Sociopsychological & $\begin{array}{l}\text { People's expression and interaction will } \\
\text { influence another person's ambition. }\end{array}$ \\
\hline Critical & $\begin{array}{l}\text { The supervision actions impound } \\
\text { ability in the organization. }\end{array}$ \\
\hline Sociocultural & $\begin{array}{l}\text { The interaction from people in } \\
\text { discussion and establish what they } \\
\text { cooperatively suggest. }\end{array}$ \\
\hline Phenomenological & $\begin{array}{l}\text { Obtain the personal experience for a } \\
\text { specific phenomenon. }\end{array}$ \\
\hline Rhetorical & $\begin{array}{l}\text { The practical art of discourse receives } \\
\text { the speaker and listeners to proceed to } \\
\text { communicate with each other. }\end{array}$ \\
\hline Cybernetic & $\begin{array}{l}\text { The organization is a system that } \\
\text { comprehends numerous interdependent } \\
\text { proportions. }\end{array}$ \\
\hline Semiotic & $\begin{array}{l}\text { The study of sign index or source that } \\
\text { extremity to another target. }\end{array}$ \\
\hline
\end{tabular}

\subsection{Representative modern theories}

The spike of organizational communication can be defined as a scientific revolution-new discovery or process of

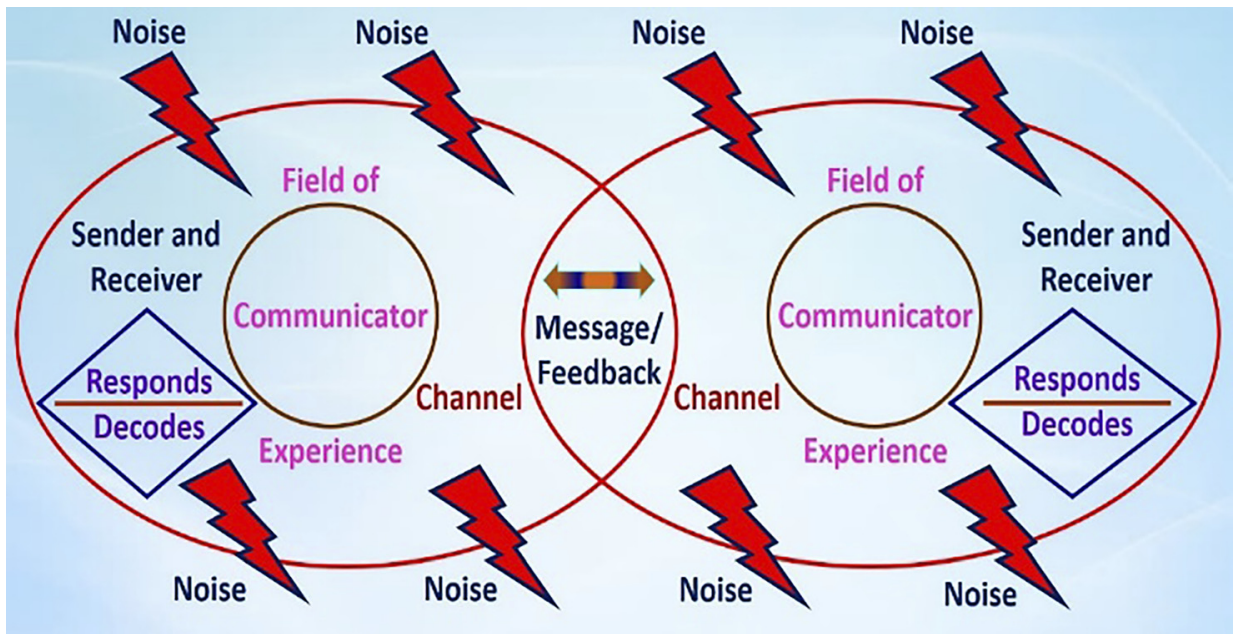

Fig. 3. Transactional model of communication travels in a simultaneous process 
glancing at the problem. Communication possesses three (3) paradigms that transpire widely perceived by scholars: the postpositive approach, interpretive approach, and postmodern approach, as defined in Table 4.

Based on Table 4, the modern theories approach is a key to enhancing management practices towards the innovative effort being accepted, on predominant issues of present organization life. Today, IS research boils down in conformity with a struggle on the legitimate study via OL approaches. The IS researches had been fostered within the conjectural fold of OL perspectives in OL which arise in the arena of human thoughts regarding the big picture of the organization world [10]. Furthermore, divergent approaches to organizational communication and integrating characteristic of those approaches. This should motivate us that each approach possesses something to contribute.

Table 4. The modern theories approach

\begin{tabular}{|c|c|c|}
\hline Paradigm & Communication & Classification \\
\hline $\begin{array}{r}\text { Postpositive } \\
\text { Approach }\end{array}$ & Systems Theory & $\begin{array}{l}\text { A biological structure } \\
\text { that gathers inputs from } \\
\text { its surroundings and } \\
\text { interacts with the } \\
\text { environment. }\end{array}$ \\
\hline $\begin{array}{r}\text { Interpretive } \\
\text { Approach }\end{array}$ & $\begin{array}{c}\text { Structuration } \\
\text { Theory }\end{array}$ & $\begin{array}{c}\text { The operation } \\
\text { structures produce the } \\
\text { outcomes for } \\
\text { mechanism } \\
\text { performance. }\end{array}$ \\
\hline $\begin{array}{l}\text { Critical or } \\
\text { Postmodern } \\
\text { Approach }\end{array}$ & $\begin{array}{l}\text { Feminist } \\
\text { Theory }\end{array}$ & $\begin{array}{l}\text { Conceptualization of } \\
\text { the futuristic } \\
\text { organization for the } \\
\text { futuristic world that } \\
\text { configures gender } \\
\text { character on a binary } \\
\text { role of thinking and } \\
\text { conception within the } \\
\text { organization. }\end{array}$ \\
\hline
\end{tabular}

\subsection{Assimilation IS in railway supplier selection excellence}

In the 1960s, the role of IS was Electronic Data Processing (EDP), for example, exchanges processing, accounting, and record-keeping. IS typically includes an organization component, as shown in Table 5.

Based on Table 5, IS comprising railway supplier selection component, where the evolution of IS in an organization, emphasis is on the decision-making and levels of management that enhance the value of information. IS can ensue clarifying technically as a pose of interconnected elements that distribute, store, process, and converge knowledge to assist control and decision-making in an organization as shown in Fig. 4.

Based on Fig. 4 levels in management provide an isolated problem-solving approach that is peculiarly applicable for addressing wicked or ill-structured scenarios. IS planning has captured significant interest between practitioners and researchers in current years because of the enormous investments that organizations encounter in IS and the progressively strategic complexion of the influence of IS on organizational performance. Since IS planning is implemented in an organizational environment, features of the organization may retain a striking impact on the effectiveness and quality of the IS planning process on organizational excellence, strategic planning, and technology innovation [11]. Furthermore, IS planning as decision making in an organization produces Information Management (IM) purposive on the strategic influence of IS on future organizations operations, the character of facilitation appliance, the feature of performance technique and the classification of strategic organization planning is strikingly related to the effectiveness and quality of IM. Transfiguration of information into knowledge is the goal of IM. IM can assist a variety of management decision-making processes and levels of decisions, as signified in Table 6 .

Based on Table 6, the IM towards railway supplier selection decision-making process plays an important role, where the organizational structure should be competent in managing the information despite the format or source such

Table 5. Information system comprise railway supplier selection component

\begin{tabular}{|c|c|c|c|c|}
\hline Component & Justification & Information System Process & Selection Process & Railway Supplier Process \\
\hline Communication & $\begin{array}{l}\text { Communicate rapidly } \\
\text { through effective and } \\
\text { efficient information. }\end{array}$ & $\begin{array}{c}\text { Achieve the performance } \\
\text { systematically. }\end{array}$ & $\begin{array}{l}\text { Structuring the functional } \\
\text { mechanism for groups and } \\
\text { individuals to act. }\end{array}$ & $\begin{array}{l}\text { Identifying and scaling the } \\
\text { nature of the business. }\end{array}$ \\
\hline Operations & $\begin{array}{c}\text { Data provides insight into } \\
\text { the organization's } \\
\text { performances. }\end{array}$ & $\begin{array}{l}\text { Chronology of the } \\
\text { organization's performance. }\end{array}$ & $\begin{array}{l}\text { Strategizing the method for } \\
\text { performance evaluation and } \\
\text { procedure for } \\
\text { implementing it. }\end{array}$ & $\begin{array}{l}\text { Chronology the incident } \\
\text { and evaluate it. }\end{array}$ \\
\hline Decisions & $\begin{array}{l}\text { Delivering all the important } \\
\text { information and modeling } \\
\text { results for decision-making. }\end{array}$ & $\begin{array}{l}\text { Administrative and } \\
\text { operational decisions. }\end{array}$ & $\begin{array}{l}\text { Interpersonal and } \\
\text { individual evaluation. }\end{array}$ & $\begin{array}{l}\text { Utilizing strategic } \\
\text { information for operational } \\
\text { decision-making. }\end{array}$ \\
\hline Records & $\begin{array}{l}\text { Stores the information } \\
\text { about the organization's } \\
\text { performance. }\end{array}$ & $\begin{array}{l}\text { Strategic planning, and } \\
\text { development for future } \\
\text { insights. }\end{array}$ & $\begin{array}{l}\text { Organization learning and } \\
\text { decision making for the } \\
\text { selection process. }\end{array}$ & $\begin{array}{l}\text { Transforming the data into } \\
\text { actionable insights. }\end{array}$ \\
\hline
\end{tabular}




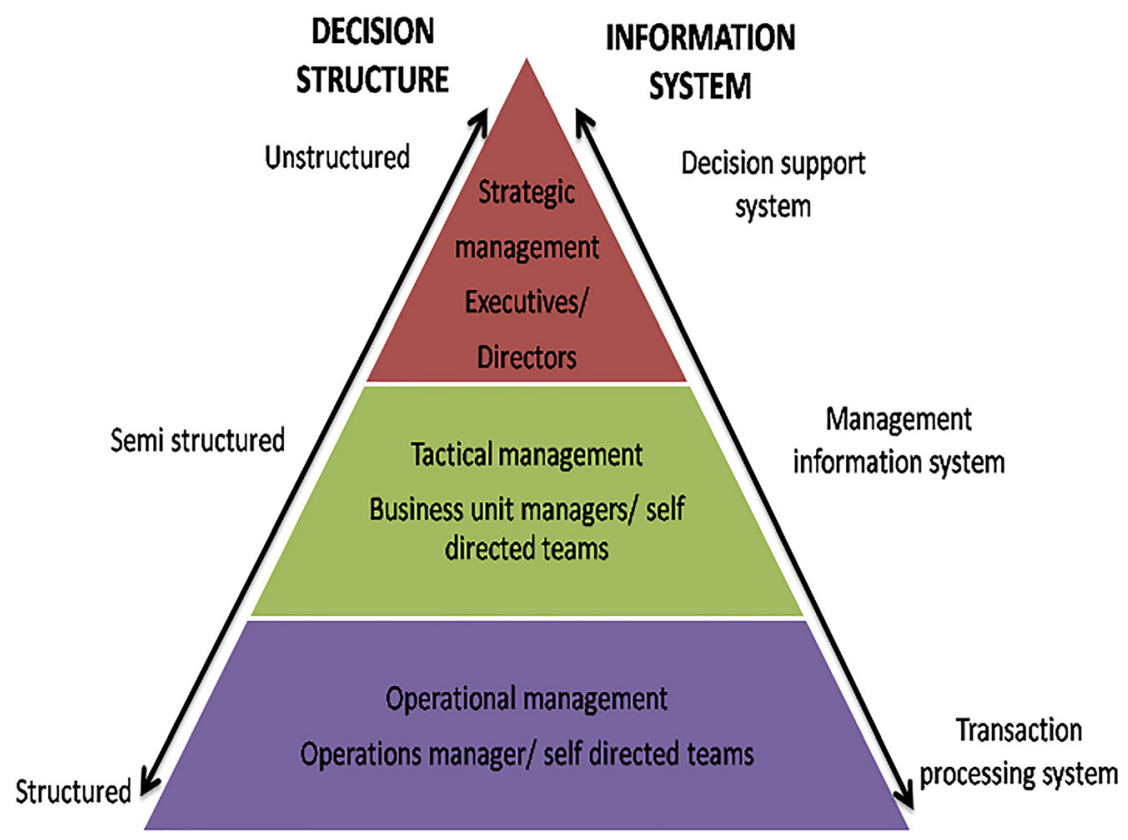

Fig. 4. Levels in management

Table 6. Information management towards railway supplier selection decision making process

\begin{tabular}{|c|c|c|c|c|}
\hline Management & Justification & Planning Structure & Levels & Decision Making Process \\
\hline $\begin{array}{l}\text { Strategic Management } \\
\text { indicates the Goals \& } \\
\text { Values. }\end{array}$ & $\begin{array}{l}\text { Focus on the goals and } \\
\text { values of the } \\
\text { organization. }\end{array}$ & $\begin{array}{l}\text { Structuring on the long- } \\
\text { range objectives creates } \\
\text { insights for the } \\
\text { organization. }\end{array}$ & $\begin{array}{c}\text { Senior Management } \\
\text { focuses on Strategic } \\
\text { planning, the duration of } \\
1-5 \text { years. }\end{array}$ & $\begin{array}{l}\text { Focus on Goal-Oriented } \\
\text { and Planning that have } \\
\text { Long-term decisions } \\
\text { making for overall } \\
\text { direction. }\end{array}$ \\
\hline $\begin{array}{l}\text { Tactical Management } \\
\text { focuses on the } \\
\text { Portfolio \& } \\
\text { Orientation. }\end{array}$ & $\begin{array}{c}\text { Focus on the strategy and } \\
\text { make it workable. }\end{array}$ & $\begin{array}{l}\text { Structuring on the short- } \\
\text { range goals through } \\
\text { planning and interpreting } \\
\text { key objectives for the } \\
\text { industry segment. }\end{array}$ & $\begin{array}{c}\text { Middle Management } \\
\text { focuses on Tactical } \\
\text { planning, the duration of } \\
6-24 \text { months. }\end{array}$ & $\begin{array}{l}\text { Focus on Objectives and } \\
\text { tasks that emphasize } \\
\text { arrangements and actions } \\
\text { of top decision-makers. }\end{array}$ \\
\hline $\begin{array}{l}\text { Operational Management } \\
\text { emphasis on the } \\
\text { Implementation. }\end{array}$ & $\begin{array}{l}\text { Focus on the results from } \\
\text { the departments, } \\
\text { workgroups, and } \\
\text { individuals. }\end{array}$ & $\begin{array}{l}\text { Structuring the work } \\
\text { standards and schedules } \\
\text { for precise actions and } \\
\text { procedures for bottom } \\
\text { levels in the organization. }\end{array}$ & $\begin{array}{l}\text { The implementation } \\
\text { Team focus on } \\
\text { Operational planning, the } \\
\text { duration of } 1-52 \text { weeks. }\end{array}$ & $\begin{array}{l}\text { Focus on Implements for } \\
\text { actionable on daily tasks } \\
\text { of the organization. }\end{array}$ \\
\hline
\end{tabular}

as physical and electronic information. Given these specifications, we can then assume that the focus of IM is the ability of KM towards managing, capturing, storing, delivering, and preserving the precise information to the accurate management at the exact time. Under the stipulation of KM, their encounter transpires a prominent dispense of effort premises upon the wisdom initiation [12]. KM can be expounded as an inventive industry, which can activate the various types of wisdom that exist in the industry to upgrade execution [13].

Whereas the scope of $\mathrm{KM}$ is wide, being a multidisciplinary approach that compasses strategy, human resource, systems, and structure. To inaugurate to comprehend regarding $\mathrm{KM}$ in the industry and to locate a portion of the circumstances by proposition of KM nowadays, including Learning Organization (LO) that is experienced at sharing knowledge, organizing, applying, and creating and at acquiring this expertise to model its organizational performance. OL depends critically upon IM by the volume to yoke the organization's knowledge capabilities and intelligence resources to stimulate organizational maturation. In this research, certain characteristics of $\mathrm{BI}$ and $\mathrm{KM}$ in contemplating the huge visualization of their decisionmaking action when accomplishing organizational execution diagnostic structure will be explained. In today's digital generation, $\mathrm{BI}$ and $\mathrm{KM}$ are duo principal techniques and models in empowering organizations towards obtaining surpass comprehension intelligence-level inception and dynamic cycle [14].

In ref [15] stressed that organizing and utilizing BI and $\mathrm{KM}$ concurrently is a vital achievement of organizational performance for commerce and adapting to complicated 
situations cognate data deluge. Furthermore, BI signifies a technology-navigate technique for presenting actionable information and analyzing data to foster corporate executives, business managers, and other end-users with more knowledgeable information and actionable organization decisions. BI encompasses modeling and simulation techniques that empower many organizations to collect data from their external sources and internal systems, as well as devise it for analyzing, running, and developing queries against the creating reports and data, dashboarding, and visualizing data to make the analytical results available for decision-makers.

\subsection{Theoretical background}

The conceptual context of the research transpires from two (2) conceptual surges of strategic performance management: the MIT 90's model and McKinsey 7S's framework. MIT's 90's model was delineated to stimulate industry to comprehend the stream of transfiguration regarding the possession of automation [16]. The MIT 90's model has critical success factors towards highlighting a few regions of the board, of a five (5)-element subsystem whose components should be in unique balance with one another to finish cohesion framework of IS perspective. On the basis of the essential literature review, the research has thought of an adjusted relationship of five (5) elements, all in association with one another as presented in Table 7.

Based on Table 7, the MIT 90's components being made from five (5) connected boundaries, intently communicate with each other, rotate to some of the elements will necessitate alternate to the different usher their aspiration and ventures once again into the arrangement. [17] states that MIT's 90's model is an emphatically adaptable model with a pivot on perception encompassing social replacement by managing industry via their acquisition of IT as a hierarchical and vital expedient from their computer mechanized domains.

In ref [18] stated that utilizing McKinsey 7S's model as the pattern intelligence foundation could be a technique for

Table 7. The MIT 90's Model Element

\begin{tabular}{|c|c|}
\hline Element & Justification \\
\hline Strategy & $\begin{array}{l}\text { Focus on utilizing Information } \\
\text { Technology (IT), for triggering serious } \\
\text { issues within the organization. }\end{array}$ \\
\hline Structure & $\begin{array}{l}\text { Focus on the planning and method that } \\
\text { interact with modern IT for practices } \\
\text { and processes within the organization. }\end{array}$ \\
\hline Management Processes & $\begin{array}{l}\text { Focus on presenting the movement } \\
\text { within the organization that consists of } \\
\text { formation, and technology. }\end{array}$ \\
\hline Individual \& Roles & $\begin{array}{l}\text { Focus on the labor force of the } \\
\text { organization that implements training } \\
\text { and education for the performance of } \\
\text { IT. }\end{array}$ \\
\hline Technology & $\begin{array}{l}\text { Focus on utilizing instruments that } \\
\text { provide better outcomes and improve } \\
\text { the organization's performance. }\end{array}$ \\
\hline
\end{tabular}

estimating organizational conduct. McKinsey 7S's model is a template for scrutinizing industry (systematic execution utilized for analysis of the explanatory characteristic of the industry) and their usefulness is integrated and coherent in essential management framework [19]. According to ref [20], McKinsey 7S's model defines the strategies and key implementation as a logical demonstrative tool, and these seven (7) specifications influence the success of an organization's prudent proposition. This different viewpoint indicative instrument is utilizing three (3) "hard" "S's" of strategy, structure, and systems, accompanied by the four (4) "soft" "S's" of shared values, style, staff, and skills [21]. On the basis of the strategic literature review, the research has thought of an adjusted boundary relationship of seven (7) components, all in communication with one another as signified in Table 8.

Based on Table 8, the McKinsey 7S's components are made of seven (7) factors by directing intelligent apropos to industrial benefit in the comprehensive perception as an outstanding instrument for surmising an organization's capacity to execute a specific policy. Evidently crucial features, for example structure, system, staff, and strategy can be commuted in the direct duration [21]. The three (3) persuade S's - style, shared values, and skills are detained elements that can barely be contrived extensive duration [22]. These models and frameworks are adopted and adapted in this research as a base of the proposed conceptual diagnostic tool.

\subsection{Conceptual model development}

Two (2) models were used to operationalize the framework; Scott-Morton's MIT90 (1991) and McKinsey 7S’s framework.

Table 8. The McKinsey 7S's Model Element

\begin{tabular}{lc}
\hline Element & Justification \\
\hline Strategy & $\begin{array}{c}\text { Focus on providing proper decision- } \\
\text { making and sustainable edge that } \\
\text { strategize the vision and mission of the } \\
\text { organization. }\end{array}$ \\
Structure & $\begin{array}{c}\text { Focus on providing knowledge on } \\
\text { structuring the organization's } \\
\text { performance for better outcomes. } \\
\text { Focus on approaches and actions that } \\
\text { need to be centralized for data analytics } \\
\text { in everyday organization performance. }\end{array}$ \\
Staff & $\begin{array}{c}\text { Focus on the workforce capabilities and } \\
\text { competencies in executing the task } \\
\text { through technology. }\end{array}$ \\
Skills & $\begin{array}{c}\text { Focus on providing proper expertise } \\
\text { that can train the organization's ability } \\
\text { and capacity to become a pioneer. }\end{array}$ \\
Style & $\begin{array}{l}\text { Focus on stimulating the organization's } \\
\text { responsibility and workforce for better } \\
\text { performance outcomes. }\end{array}$ \\
Shared Values & $\begin{array}{c}\text { Focus on optimizing the organization's } \\
\text { foundation through IT that can control } \\
\text { human behavior and performance } \\
\text { activities. }\end{array}$ \\
\hline
\end{tabular}


The executes of socio-specialized angles could assist the study to grasp the key parts of industrial nature. Furthermore, the study has figured the IS in railway supplier selection excellence conceptual model for an enterprise framework development, as shown in Fig. 5.

Based on Fig. 5, the study started addressing and viewing the MIT 90's model and McKinsey 7S's framework in embracing and adjusting to broad key, perfect reasoning of operational and tactical analytics on strategic dynamic cycle usage boundaries of an industry perspective. This characteristic information is applicable and comprehensible for reporting and decision purposes by providing functional information to the organization for strategic decision making. Furthermore, the study has tabulated the assimilation of elements and components of the railway supplier selection excellence framework as shown in Table 9.

Table 9 has summarized the assimilation of elements and components of the railway supplier selection conceptual model, focusing on relevance, reliability, comparability, and consistency. To develop the generic structure, the research has tended to key approaches and procedures dependent on the impacts of the perfect logic of railway supply chain conceptual model for greatness and systematic on essential usage - the primary purpose behind receiving and adjusting the segments for BI system. Meanwhile, BI moves with a new prescient model and unveils what will be the outcome in the industry [23]. New BI systems have begun to unveil how all the different pieces of the industry cooperate to furnish a result and industry pioneers can ultimately observe the enormous notion and make rapid, finer-knowledgeable choices [24]. And next, the research will design and develop the details of the railway supplier selection excellence framework as appears in Fig. 6.

Based on Fig. 6, the railway supplier selection excellence framework-is a mashup conceptual design that distributes as the core for the decision-making process. The study scrutinizes varied ways to design philosophy research for IS proposing and develops four (4) parts, each dealing with a vital characteristic of IS development to be considered in organization analysis. Thus, in planning the pertinent comprehensive framework, we began tending to and seeing combined McKinsey 7S's and MIT90s frameworks in embracing and adjusting to generic key, ideal reasoning of strategic and operational intelligence on methodology execution segments of an industry's decision-making perspective. We had presumed that there are comparative elements of McKinsey 7S's framework, MIT 90's model, and the comprehensive railway supplier selection as a case study.

\section{CONCLUSION}

For the railway supplier selection to forge expertly knowledgeable options, their execution management systems need to yield the recently obtainable execution information. BI and KM utilize information to prosper wisdom in structure to permit preferable conclusion composition by utilizing data to solve information glut and knowledge sharing. The study revisits case study objectives and evaluates the findings of the extant literature on the adoption of the strategic dynamic cycle. Then the dynamic plan was analyzed and developed using the principles of strategic performance diagnostics approaches, the principle of $\mathrm{KM}$, and the heuristic principle.

\section{IS in Organization: Conceptual Model}

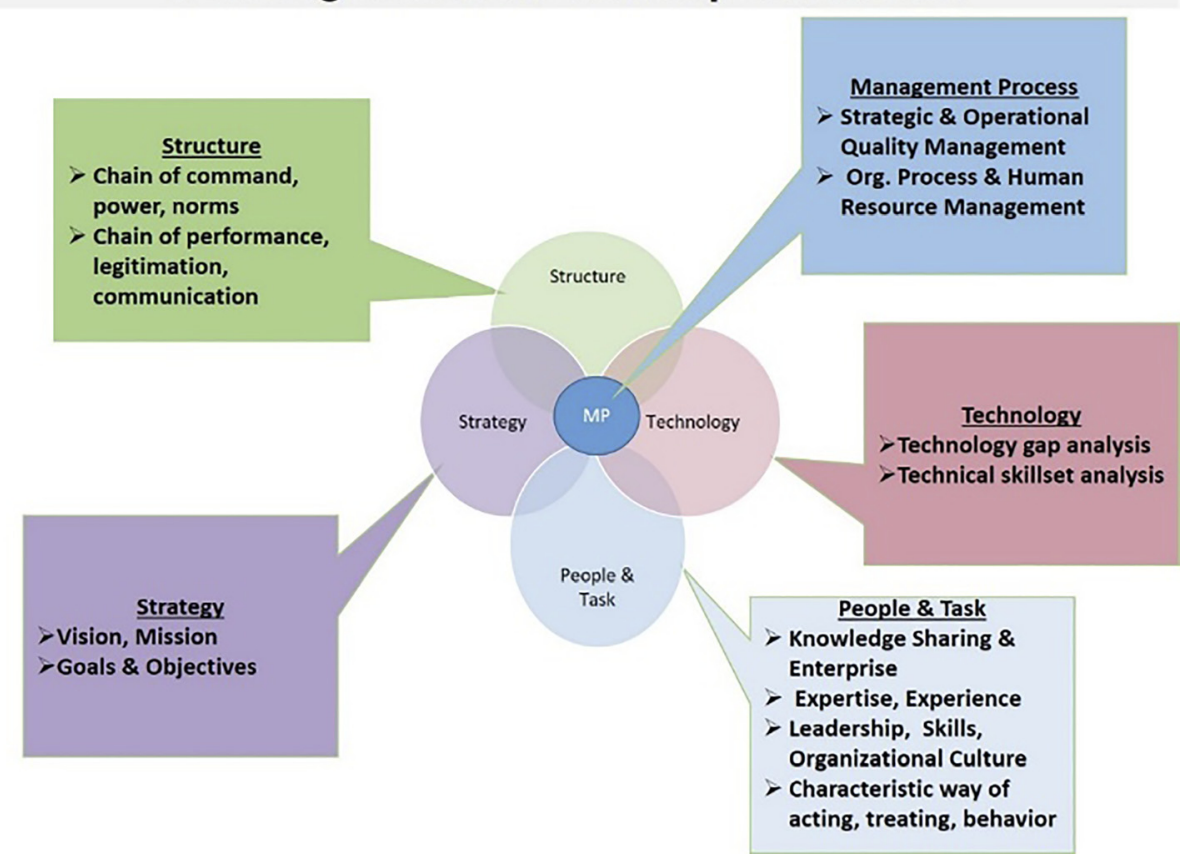

Fig. 5. The IS in railway supplier selection excellence conceptual model development 
Table 9. The assimilation of elements and components of railway supplier selection conceptual model

\begin{tabular}{lll}
\hline Components & Criteria & Function \\
\hline
\end{tabular}

1. Systems focus on Relevance

Identifying the systems through their functions provides information for decision-making.

2. Perspectives focus on Reliability

Identifying the perspectives thorough organization information and verification of the results.

Focus on the planning, controlling,

3. Development focus on Comparability

4. Quality focus on Consistency

Focusing on data analytics through external and internal information on the organization's performance. a) Identifying the important problems that are expected or important to be solved soon.

b) Identifying the security and robustness of the system for better operational and technical challenges.

c) The ability of the organization to use the systems for decision making.

a) Providing new experiences and viewpoints through IT that strategized decision-making.

b) Providing a framework that can examine and verify the organization's performance.

c) Implementing systems thinking empowers the organization through communication and generates better performances.

a) Creating an insightful system that enhances decisionmaking.

b) Designed a problem-solving system that can employ within the groups or organization environment that can provide the solution.

c) Transforming the organization into digitalization that can provide values and practices for accomplishing the organization's goals.

a) Focus on the strategic approaches that can be adopted for organization performance and building a long-term

relationship through technical and economic capability.

b) Providing quality data for improving decision-making that can generate intelligent decisions for organization performance. c) Utilizing IT for organization operation and decision making.

\section{IS in Organization: Conceptual Model}

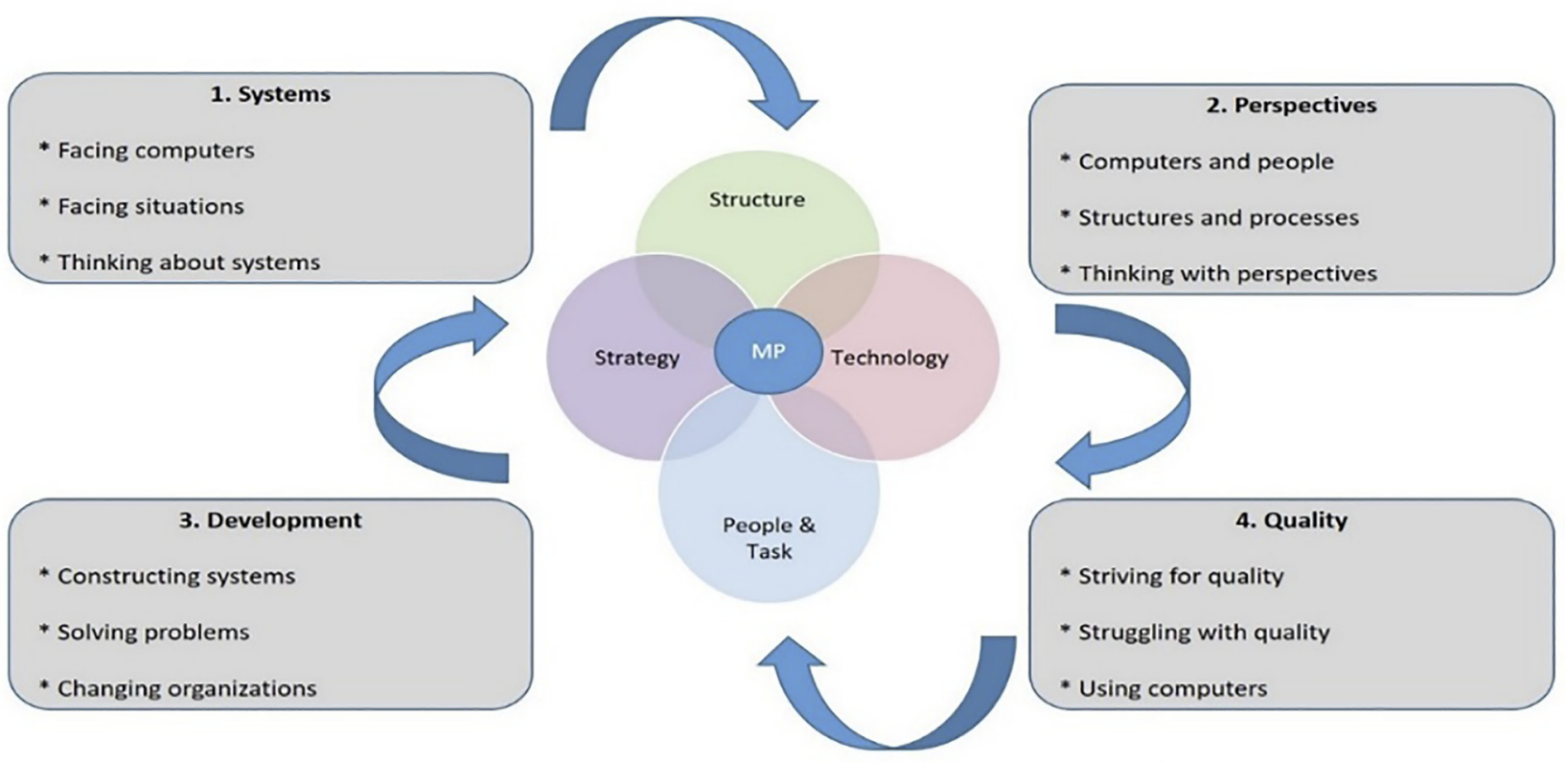

Fig. 6. The railway supplier selection excellence framework-a mashup conceptual design 
The case study was carried out to find answers and to yield a perspective and an instrument for systematic decision support by analyzing the insight of railway supplier selection - a conceptual design. The objective of the case study is to ascertain the philosophical knowledge of holistic approaches. In this study, the conceptual framework design proposed a viable vital dynamic that could help the decision-makers in dynamic cycles and models from behavioral decision and heuristics view in an organization. Moreover, we review the BI precision and rating from a technical and managerial perspective and as an enabler of railway supplier selection excellence. BI is a management outlook and device that assists the railway supply chain to organize and clarify supplier knowledge for the objective of inventing functional decisions making by utilizing specific-position and computerized decision-making. The leading benefaction of this study is utilizing the principle of philosophical knowledge on holistic approaches and socio-technical perspective and human behavior context approach in settling the poor key dynamic apparatus plan in the decision-making framework.

\section{ACKNOWLEDGEMENT}

The authors would like to thank the anonymous reviewers and the editor for their suggestions to improve the article. The authors also want to express gratitude toward Universiti Teknikal Malaysia Melaka (UTeM) for the UTeM Zamalah Scheme for supporting and sponsorship this research work.

\section{REFERENCES}

[1] B. Baesens, R. Bapna, J. R. Marsden, J. Vanthienen, and J. L., Zhao, "Transformational issues of big data and analytics in networked business," MIS Quarterly, vol. 38, no. 2, pp. 629-31, 2016. Available: http://www.airccse.org/journal/ijgca/papers/3212ijgca03.pdf.

[2] M. Jayakrishnan, A. K. Mohamad, and A. Abdullah, "Enterprise architecture embrace digital technology in Malaysian transportation industry," Int. J. Eng. Adv. Technol., vol. 8, no. 4, pp. 852-9, 2019b. Available: https://www.ijeat.org/wp-content/ uploads/papers/v8i4/D6444048419.pdf.

[3] G. Anthony Gorry and M. S. S. Morton, "A framework for management information systems,” vol. 71, no. 51, pp. 458-70, 1971.

[4] M. Jayakrishnan, A. K. Mohamad, and A. Abdullah, "A systematic literature review in enterprise architecture for railway supply chain of Malaysia transportation industry," Int. J. Eng. Res. Technol., vol. 12, no. 12, pp. 2473-8, 2019a.

[5] A. Vahidi, A. Aliahmadi, and E. Teimoury, "Researches status and trends of management cybernetics and viable system model," Kybernetes, vol. 48, no. 5, pp. 1011-44, 2019. Available: https://doi. org/10.1108/K-11-2017-0433.

[6] P. Jarzabkowski, and R. Whittington, "A strategy-as-practice approach to strategy research and education," J. Manag. Inq., vol. 17, no. 4, pp. 282-6, 2008. Available: https://doi.org/10.1177/ 1056492608318150 .
[7] V. Potočan, M. Mulej, and Z. Nedelko, "Society 5.0: Balancing of Industry 4.0, economic advancement and social problems," Kybernetes, 2020. (ahead-of-print). Available: https://doi.org/10. 1108/K-12-2019-0858.

[8] M. Jayakrishnan, A. K. Mohamad, and M. M. Yusof, "Strategic information system for decision making in railway supply chain management," Int. J. Adv. Trends Computer Sci. Eng., vol. 9, no. 3, pp. 3988-94, 2020b. Available: https://doi.org/10.30534/ijatcse/ 2020/223932020.

[9] M. N. Uddin and M. Hamiduzzaman, "The philosophy of science in social research," J. Int. Soc. Res., vol. 2, pp. 654-64, 2009.

[10] A. Pritchard, N. Morgan, and I. Ateljevic, 2011, "Hopeful tourism. A new transformative perspective," Ann. Tourism Res., vol. 38, no. 3, pp. 941-63. Available: https://doi.org/10.1016/j.annals.2011.01. 004.

[11] M. Jayakrishnan, A. K. Mohamad, and M. M. Yusof, "Digitalization railway supply chain 4.0: Enterprise architecture perspective," Int. J. Adv. Trends Computer Sci. Eng., vol. 9, no. 5, pp. 9056-63, 2020a. Available: https://doi.org/10.30534/ijatcse/ 2020/310952020.

[12] M. Al Qady and A. Kandil, "Automatic classification of project documents on the basis of text content," J. Comput. Civil Eng., vol. 29, no. 3, p. 04014043 , 2015. Available: https://doi.org/10.1061/ (ASCE)CP.1943-5487.0000338.

[13] S. C. Pandey and A. Dutta, "Role of knowledge infrastructure capabilities in knowledge management," J. Knowledge Manag., vol. 17, no. 3, pp. 435-53, 2013. Available: https://doi.org/10.1108/ JKM-11-2012-0365.

[14] J. S. Aldairi, M. K. Khan, and J. E., Munive-Hernandez, "A hybrid knowledge-based lean six sigma maintenance system for sustainable buildings," in Transactions on Engineering Technologies, Singapore: Springer Singapore, pp. 355-69, 2016. Available: https://doi.org/10.1007/978-981-10-1088-0_27.

[15] O. L. Frank, S. A. Omer, S. B. Riffat, and B., Mempouo, "The indispensability of good operation \& maintenance (O\&M) manuals in the operation and maintenance of low carbon buildings," Sustain. Cities Soc., vol. 14, pp. e1-9, 2015. Available: https://doi. org/10.1016/j.scs.2014.06.002.

[16] A. Caroline, "Kajian Konsep MIT 90's Sebagai Salah Satu Kerangka Kerja untuk Membangun," Sistem Informasi Bisnis, vol. 4, no. April, pp. 93-102, 2018.

[17] V. Mistry, "Benchmarking e-learning: Trialling the "MIT90s" framework". Benchmarking: Int. J., vol. 15, no. 3, pp. 326-40, 2008. Available: https://doi.org/10.1108/14635770810876629.

[18] D. Teh and B. Corbitt, "Building sustainability strategy in business," J. Business Strategy, vol. 36, no. 6, pp. 39-46, 2015. Available: https://doi.org/10.1108/JBS-08-2014-0099.

[19] A. Singh, "A study of role of McKinsey's 7S framework in achieving organizational excellence," Organizational Develop. J., vol. 31, no. 3, pp. 39-50, 2013.

[20] E. Fabbri, "Strategic planning and foresight: The case of smart specialisation strategy in tuscany," Foresight, vol. 18, no. 5, pp. 491-508, 2016. Available: https://doi.org/10.1108/FS-06-20150036.

[21] İ. Gökdeniz, C. Kartal, and K. Kömürcü, "Strategic assessment based on $7 \mathrm{~S}$ McKinsey model for a business by using analytic network process (ANP)," Int. J. Acad. Res. Business Soc. Sci., vol. 7, 
no.6, pp. 2222-6990, 2017. Available: https://doi.org/10.6007/ IJARBSS/v7-i6/2967.

[22] M. R. Lee and T. T. Chen, "Revealing research themes and trends in knowledge management: From 1995 to 2010," Knowledge-Based Syst., vol. 28, pp. 47-58, 2012. Available: https://doi.org/10.1016/j. knosys.2011.11.016.
[23] M. Rutendo, Leveraging Business Intelligence and Analytics to Improve Decision-Making and Organisational Success. University of Cape Town, 2017. Available: http://hdl.handle.net/11427/27408.

[24] M. Gadu and P. N. El-khameesy, "A knowledge management framework using business intelligence solutions, vol. 11, no. 5, pp. 102-7, 2014. 